2009

\title{
Arguments For and Against Social Rights
}

Garrido Gómez

Follow this and additional works at: https://scholarlycommons.law.case.edu/swb

Part of the Human Rights Law Commons, and the Social and Behavioral Sciences Commons

\section{Recommended Citation}

Garrido Gómez. 2010. "Arguments For and Against Social Rights." Societies Without Borders 4 (2): 158-174.

Available at: https://scholarlycommons.law.case.edu/swb/vol4/iss2/5

This Article is brought to you for free and open access by the Cross Disciplinary Publications at Case Western Reserve University School of Law Scholarly Commons. It has been accepted for inclusion in Societies Without Borders by an authorized administrator of Case Western Reserve

University School of Law Scholarly Commons. 


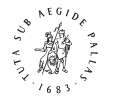

\title{
Arguments For and Against Social Rights*
}

\author{
María-Isabel Garrido Gómez \\ University of Alcalá, Spain
}

Received 1 October 2008; accepted 28 December 2008

\begin{abstract}
I investigate the semantic and practical complexity of social rights, together with the obligations which correspond to the public authorities in terms of putting them into practice. I also discuss the role of meaningful economic equality in the discourse of social rights, explaining the points at which the two concepts interact, and the ways that formal equality can be improved. Finally, I reach the conclusion that there are two distinct meanings of the concept of discrimination, one which is equivalent to any violation of the general principal of equality, and another stricter one, which is the infringement of equality when any of the proscribed differentiating factors are present (race, sex, etc.). The legal aspect of the mandate to exercise and guarantee social rights is manifest in the programmed objective, as well as in the fact that the measures aimed at this objective are protected from the possibility of compliance.

In this way, social rights constitute subjective rights, representing a programme through which goods would be distributed evenly among public, collective and private interests. This results in a singular structure with a special mechanism by which the State has to provide assistance and services, and create, strengthen and promote the conditions allowing individuals and groups to satisfy their needs. Thus their obligations are also related to the prerequisites for exercising positive liberty. The main point of departure is that individuals are moral subjects endowed with dignity. It defends the idea that we all have real capacity for choice and that we all direct our existence towards certain aims in life.
\end{abstract}

\section{Keywords}

social rights, liberty, equality

\section{A Starting Point: Some Challenges of Social Rights}

Indeed, with changes that have taken place, the liberal paradigm now considers that members of a society are actors in a market economy which

*) Consolider-Ingenio 2010. The Age of the Rights. CSD2008-00007. 
guarantees the real conditions ensuring individual rights. Thus the recognition of an individual right represents the exercise of private autonomy by the stipulation of contracts and the acquisition of goods or services from others. In this kind of State, the structure of rights assumes that women, racial minorities, gays, the disabled etc., fit into the present scheme for 'natural' reasons, without taking into account the underlying problem. ${ }^{1}$ The process of transformation takes shape in a number of forms: the move from formal competence towards substantive content; the use of 'recognition rules' and 'fundamental and structural values'; the increase in 'protection clauses'; the proposals for 'weighting clauses', 'identity', 'hierarchy' and 'compensation' guarantees; the constitutional development of 'operational rules'; and the extension of fundamental rights thank to 'rules governing the applicable law'. ${ }^{2}$

There was no formal mention of constitutionalized social rights until the Mexican (1917) and Weimar (1919) Constitutions, which were created according to a series of political, economic and ideological factors adapted to the industrial and post-industrial age. The precursors are von Stein (Geschichte der sozialen Bewegung, 1850) and his doctrinal mentor Heller (Rechtsstaat oder Diktatur, 1929). The Basic Law of the Federal Republic of Germany of 1949, a little later, is also worth highlighting because it includes the idea of the social State (articles 20 and 28), with demands linked to objectives that increase the reach of liberal States based on the rule of law, guaranteeing 'freedom', 'property', 'equality', 'legal security', and 'rights of political participation'. In this scheme, the public authorities are responsible for providing the citizens with the means which individuals need to develop their personalities and integrate socially, eliminating abstentionism. ${ }^{3}$

The actions of the State have to be directed towards ensuring individual freedom and protecting the autonomous development of subjects. The State organization and its regulation have to be governed by rational principles, which can be transferred to the law as a basic element. As a result, this system tries to ensure that the State and its organs can only act in accordance with the powers granted them by the legal system, by which they are thus limited. In this way, legislation applies to all on an equal basis and arbitrariness in public powers is eliminated.

\footnotetext{
1) Barcellona 1999, p. 105; Tuori 2000, p. 22.

2) Häberle 2003, p. 108.

3) Díaz 1998, pp. 103, 106; García-Pelayo 1996, pp. 18-20.
} 
In addition, it should be stressed that fundamental rights form an essential nucleus within Rules of law in a broad sense, and also constitute an essential legitimizing element, whilst demanding and requiring such a Rule of law. In this way, since the end of the 18th century, the theory of rights has offered a new form of understanding political power and the dimension of the State. ${ }^{4}$ According to the liberal theory of fundamental rights, such rights are an individual's right to freedom in the face of the State. The freedom of individuals, from the legal point of view, precedes public authority, which has to ensure the means and institutions needed for its legal guarantee. The fundamental rights as rights to liberty are rules for the distribution of competences between individuals (society) and the State. They delimit the sphere in which individuals and their social structures can be trusted to regulate conduct and organize their own maintenance. ${ }^{5}$

The liberal concept of rights has its main corollary in Locke's statement: "The greatest and principal aim which men seek when joining a State or communities, and submitting to a government, is to safeguard their goods". ${ }^{6}$ These goods belong to all men in an equal way, so that we can say that they are individual. They consist of life, liberty and property. The natural order unfolds in a set of innate and inviolable rights, and the State has been constituted to protect them. It has to adopt the most suitable organic structure possible, so that civil rights are the ideal framework for defending the sphere of individual sovereignty against any interference by the public sphere. Authors such as Bentham, Locke, Mill, Constant and Tocqueville stressed negative freedom, placing great importance on protection from the State, of a more or less radical nature according to each theory. For the neo-liberal tradition, represented by Buchanan, Friedman, Hayek, Nozick, Posner and Tullock, the most important point is individual freedom conditioned by the freedom of the market, and defined as an instrument of convergence between efficiency and justice. In this way, the role of the State is reduced to that of an arbiter, laying down protective or repressive rules, and making use of sanctions in the case of non-compliance. When there is a conjunction of legal freedom, the right not to be interfered with by the State, and the competence to exercise the right, the State cannot interfere with liberty. ${ }^{7}$ Thus the legal, economic and political arguments

4) De Asís 1999, p. 43; Martínez de Pisón 1997, pp. 31, 32.

5) Böckenförde 1993, p. 48.

6) Locke 1982, 9, $\$ 124$.

7) Harvey 2005, pp. 64-87. 
are articulated in a cohesive fashion, postulating an extremely restricted role for the State. ${ }^{8}$

According to this theory, in a liberal rule of law, not only is negative liberty what defines individual autonomy, but equality also becomes more important, at least in one of its aspects, since there is no doubt that the concept of equality and its practice are connected with fundamental rights: those of liberty (since they are rights to equality with respect to possible differences) and those of society (since they are rights to the reduction of inequalities). With regard to this, Mill stated:

The sole end for which mankind are warranted, individually or collectively, in interfering with the liberty of action of any of their number, is self-protection. That the only purpose for which power can be rightfully exercised over any member of a civilized community, against his will, is to prevent harm to others. His own good, either physical or moral, is not a sufficient warrant. He cannot rightfully be compelled to do or forbear because it will be better for him to do so, because it will make him happier, because, in the opinions of others, to do so would be wise, or even right. ${ }^{9}$

Thus if there is an essential equality between all men, based on equal rights from birth, one can distinguish from this a formal equality or equality before the law, which is linked to a generality and abstraction, separate from personal, social and economic conditions which may originate from differences in the effective enjoyment of rights and freedoms which are regulated by law. This equality which establishes legal certainty, is given practical form in the application of the law, an impartial application of legal criteria to those who are objects of the rule of law, and in the content of the law, relative to the justification and reasonableness of the criteria used legally to differentiate between individuals.

Liberalism aims to justify this equality on the premises from which its theory is constructed, i.e. from legal equality which is proof of a normative individualism. Accordingly, individuals are the subjects of legislation; and of an ethical individualism, which explains that they are in some way rational and capable of having plans for their lives, interests, and other pursuits, and that the satisfaction of these properties is a value. ${ }^{10}$ The role which the State has to play corresponds to a neutrality in the face of individual

8) Martínez de Pisón 1996, pp. 242-244.

9) Mill 2003, pp. 57-74.

10) Rivera 1997, pp. 26 and 27. 
preferences, and the fundamental idea that liberties require an equal treatment for all subjects, men and women, rests on the concept of autonomy.

\section{Arguments for Social Rights}

A legal guarantee is a functional, relational and multidimensional reality that can be analysed within a legal system. As far as social rights are concerned, it is necessary to distinguish between the possibilities of technical and political realization. Technically they can be guaranteed, because the acts required to satisfy them would inevitably be discretional, unable to be formalized and would not be susceptible to jurisdictional controls and constraints. For that reason, the complexity of guaranteeing social rights is essentially political. Ferrajoli talks of 'primary guarantees,' of prohibitions and obligations that go hand in hand with the rights and, similarly, of the relationships that exist between what is permitted and what is prohibited, and between what is permitted and what is not compulsory. ${ }^{11}$ The 'secondary guarantees' are related to the responsibilities of the judicial organs to apply sanctions or declare annulments, if there are invalid or illegal acts that infringe the obligations or prohibitions that constitute the primary guarantees. In this way, the question of guarantees means that there are rights with a greater degree of resistance than others depending on what the authorities have decided. Guastini ${ }^{12}$ even goes so far as to talk of 'real rights' and 'presumed rights'.

The rights serve to limit the official authority in order to add to its definition and to obtain the support and help it offers in the form of benefits and services. In relation to civil society they serve to defend its members from the official authority and from themselves, to be effective and surpass the natural state, to communicate and establish links between the official authority and the civil society, instead of having the official authority separated from society or a civil society that does not consider the official authority. In short, the purpose of the entire public service must be to ensure the enjoyment of rights and promote them. ${ }^{13}$ We draw the conclusion that the actions of the State which we have set out should be modernized and improved constantly, because, given the growing scarcity of many

11) Ferrajoli 2005, pp. 19-56 y 139-196.

12) Guastini 1994, pp. 133-134.

13) Peces-Barba 1999b, pp. 131-155. 
goods and having achieved universal social rights, in many cases the demands are excessive and impossible to meet. Given the problems that arise when determining when someone is entitled to State's action, the decision-making becomes increasingly more complicated. ${ }^{14}$

The contemporary concept of equality has its origin in the creation of a legal and social order in which the independence of the individual could only be obtained by positioning it under the auspices of the legal power of the State, with the concept of independence being linked to a formal system and economic autonomy. As Rosenfeld highlights, the history of constitutional equality is the result of a long and difficult struggle against feudal status and privileges. This is a dialectical struggle divided into three stages. In the first, difference is a correlate of inequality: "Those who are characterized as different are treated as inferiors or superiors depending on their position in the hierarchy". In the second phase, identity is a correlate of equality: "If certain criteria are met, everyone has the right to be treated equally". Finally, difference is the correlate: "Any person shall be treated in proportion to their needs and aspirations". ${ }^{15}$

Initially, social rights can be defined as those which establish a benefit or service for holders of the right. The benefit comes mainly from the public authorities but also less commonly from individuals. ${ }^{16}$ They take the form of rights to substantive equality, i.e. they demand a legal system which differentiates according to real inequality, so that this equality is a condition of the exercise of fundamental rights. ${ }^{17}$ Given this aim, the problems related to guarantees of satisfying these rights differ from those of other classes of rights. ${ }^{18}$ In this respect, Bovero believes that, neither the constitutionalization nor internationalization of fundamental rights can be reduced to theoretical declarations based only on a rigorous distinction between them and on their safeguarding. ${ }^{19}$ The contradiction between the declaration and the rights themselves must be resolved, in order to determine the proper system for guaranteeing the rights.

\footnotetext{
14) Donati 1990, pp. 51-81; Eekelaar 2000, pp. 9-28.

15) Rosenfeld 1996, pp. 161-192.

16) Prieto points out $(1998$, pp. 72,73$)$ that this does not always occur, since by its nature, the rights to strike and trade union freedom do not involve any provision, unless the public protection offered for them is considered a provision. Other cases would be those related to those rights which restrict individual autonomy in employment contracts.

17) Ollero 1989, p. 14.

18) Ferrajoli 2007, pp. 108, 109.

19) Bovero 2007, p. 229.
} 
This indicates how pernicious it is if society regulates itself freely: administrative, economic, decisional, etc., techniques are essential to break the autonomy of the systems of State and society. This connection should be grounded in the development or control of systems without which one cannot live today, the security of those aspects which are vital for human life, and a range of social benefits which are guaranteed constitutionally. The social benefits can be summarized as follows:

1. regulation of a minimum wage, revised according to changes in the economic situation; a policy of full employment.

2. care for people who are temporarily or permanently incapacitated for work.

3. career training, supported by a fair distribution of income according to the economic situation. ${ }^{20}$

The term 'social policy' refers to the institutionalized mechanisms of public authorities, or preferential guidelines which frame State responsibility for the welfare of its citizens historically and structurally. ${ }^{21}$ In this respect, using the arguments of Barcellona to deepen our understanding of equality, there is a link between the transformation of the liberal idea of a State governed by the rule of law and the crisis of formal equality, together with the arrival of democracy as a substantive principle and procedure. Barcellona comments that substantial inequalities make substantive equality necessary, even though there is only the barest outline of a differentiated treatment of actual situations. The criticism which he makes is that "the principle of substantive equality is the negation of positive law and therefore, of the self-created character of imposed rules, precisely because it brings with it a reference to criteria of substantive justice and meta-positive elements"... "It is no coincidence that equality is a form of rule (equal right) and substantive content of the mandate (equality of different situations). Nor is it a coincidence that formal equality (as a means) should exclude the relevance of substantive inequality, and vice versa, that substantial equality (as an end) should violate formal equality... Paradoxically, equality has to negate diversity (hierarchies) but should also prevent homologation (the homogenized society). Its duty is to square the circle". ${ }^{22}$

\footnotetext{
20) García-Pelayo 2005, pp. 21-25, 29, 30, in terms of the content of 'existential provision' defined by Forsthoff.

21) Garrido 2007, p. 111.

22) Barcellona 1996, pp. 52, 74.
} 
Linked to the main discussions which add the satisfaction of social rights and programmes of substantive equality, numerous solutions have been designed by various authors. Preuss systematizes the strategies into four groups: The first suppresses distributive rights, which are a handicap for the market to use its function of assignation. This proposal is not admissible because the results would restore the hegemony of the bourgeoisie and run the risk of subjecting the working class to the market, making political dictatorship a real possibility. The second lays bare the conversion of substantive rights into procedural rights, prejudicial to persons who are not capable of pursuing their interests effectively because of lack of resources. The third is linked to what has been called 'responsible right', contained in article 18 of the German Grundesetz, which determines the loss of constitutional rights involved in an inappropriate use, i.e. a use which takes no account of the negative derivations of the constitutional system as a whole, which could devaluate legal claims. The fourth pertains to the 'teubnerian doctrine' of 'reflexive law' which calls for a constitutionalization of an organizing conscience of organizations in response to social demands. $^{23}$

\section{A New Comprehension of Equality for the Realization of Social Rights}

There is a basic legal equality to which we are all subjects in law, with corresponding rights and obligations. Formal equality is linked to generality and abstraction. Applied to rights, this means that we are all equal in terms of holding and exercising rights. The idea of formal justice satisfies the value of equality in the way that subjects to whom rules are applied have to adapt to them. The fact that this equality is relative, depending on the criterion that has inspired the rule in question, the number of advantages or disadvantages to distribute, and the number of persons affected by the rule, does not alter the fact that compliance with results in equal treatment. ${ }^{24}$

Equality as a starting point is identified with formal equality, which runs into obstacles which are indirectly protected by law, resulting from wealth or chance, which make persons with the same capacity have unequal opportunities. Legal equality is indispensable for acquiring real equality in a negative sense, given that the concurrence of legal discriminations limit

23) Preuss 1991, pp. 88, 89.

24) Bobbio 2001, pp. 17, 18; Laporta 1985, pp. 3-31. 
the objectives which have been set. At the same time, in a positive sense, it allows persons to go before the courts to challenge discrimination. However, formal equality is not sufficient. It requires an effective application of egalitarian laws and laws which safeguard vulnerable areas: the principle of 'social equalization' compensates inequalities by raising or promoting disadvantaged people, or limiting or reducing the wealth and power of the most fortunate. The former case offers positive benefits, and the latter negative ones. ${ }^{25}$

Given the idiosyncratic nature of equality and the fact that it starts with diversity, its evaluation excludes identity and similarity. Identity deals with two distinct subjects, and does not recognize elements which differ. Similarity does not require differentiating elements to be disregarded. When we make a judgement regarding equality, we have to make a relational operation, making clear that something is equal to another thing with which we are comparing it. This point involves a value judgement which considers certain facts and inherent inferences. ${ }^{26} \mathrm{~A}$ case of equality of treatment would be when $\mathrm{A}$ and $\mathrm{B}$ are treated equally by $\mathrm{C}$, if $\mathrm{C}$ gives the same benefit or specific detriment to $\mathrm{A}$ and $\mathrm{B}$. Whether $\mathrm{A}$ and $\mathrm{B}$ receive an equal distribution depends on the rule applied. The principle can be broken down into the obligation which the legal system has to prevent a priori any form of negative discrimination becoming positive, and implanting positive discrimination on cases which have traditionally involved situations of inequality. In this respect, it is interesting to mention the opinion of Ruiz Miguel relating to relative equality rules, determining equal treatment for a certain category of persons, inasmuch as this treatment is given to another category, and non-relative equality rules, determining the rights and duties of various persons without reference to the relationship between them. ${ }^{27}$

In substantive equality, affirmative and negative judgements of equality are not absolutely symmetrical. The fact that two individuals, or classes of individuals, are substantially equal is interpreted as a duty to treat them in the same way. It is a legal policy directive aimed at legislators or judges. According to Guastini, this presupposition can be formulated as a normative proposition within the terms given as follows: "There is at least one rule which attributes to ' $\mathrm{x}$ ' and ' $\mathrm{y}$ ' distinct subjective legal situations'. The statement that two individuals, or classes of individuals, are not substan-

25) Fernández Ruiz-Gálvez 1992, pp. 156-158.

26) Prieto 1995, pp. 112-115.

27) Santamaría 1997, p. 295. 
tially equal is made according to the circumstances and the context of the discourse. We can use a principle holding to this postulate to express the guideline that there has to be different treatment, and to express that the subjects, or a group of them, should be made equal. ${ }^{28}$

The question which has to be addressed is what the foundation for substantive equality in the discourse of social rights is. The answer has to be rooted in the response to human needs, which are either themselves not negotiable, or are based on circumstances which are not negotiable, and which signify a manifestation of the capacity to overcome the limits of their existence. ${ }^{29}$ Those who do not have their basic needs guaranteed have the satisfaction of these needs protected in the form of rights. ${ }^{30}$ Graphically, Zimmerling argues that " $\mathrm{N}$ is a basic need for $\mathrm{x}$ if, and only if,, under the circumstances given in the socio-cultural system $S$ in which he lives and given the personal qualities $\mathrm{P}$ of $\mathrm{x}$, the non-satisfaction of $\mathrm{N}$ prevents $\mathrm{x}$ from carrying out any non-contingent goal, and thus from following his overall life plan". To sum up, a human need is identified by the damage which its non-satisfaction produces for the person. ${ }^{31}$

The techniques of dealing with equality of substantive treatment are equality as 'equivalence' and as 'differentiation'. The former deals with the respect and protection of basic needs as an element whose rationality and foundation for rights is entirely acceptable. The latter consists in the disappearance of a privilege within its estimation as a fundamental right, insofar as: it is interpretable as equality of substantive treatment as equivalence, since the differential circumstance is not relevant for creating an inequality; it establishes a civil right which obliges the public authorities to satisfy a need which cannot be satisfied by privation; and it determines principles that demand to be dealt with later by legislation. ${ }^{32}$ On this subject, we wonder what distribution leads to adequate compensation, given that meeting point between the legal equality defined in legislation and the action of public authorities to achieve substantive equality is far from clear. As Gíménez Glück points out, it is difficult to be precise on "when the principle of equality is being complied with", "when formal equality is transgressed in order to achieve substantive equality", or "when

\footnotetext{
28) Guastini 1999, pp. 196-198.

29) Añón 1994, pp. 191, 193.

30) Añón 1994, pp. 265, 266; Contreras 1994, pp. 52-54.

31) Zimmerling 1990, p. 51; Bayón 1991, pp. 43-45; Martínez de Pisón 1998, p. 166.

32) Añón and García Añón 2002, pp. 153, 154; Peces-Barba 1999a, p. 291.
} 
the traditional outlines of formally equal treatment is being respected scrupulously" ${ }^{33}$

Thus it is worth outlining the grey area between "differences" (characteristics which differentiate and at the same time make persons individuals) and "inequalities" (disparities between subjects originating in rights related to wealth and positions of power or subjection). Despite discrepancies, we note that the two concepts, "differences," and "inequalities," are linked to the fundamental rights of liberty, in terms of the equal respect to all differences, and to social rights, in terms of the rights to reduction of inequality. ${ }^{34}$ These are the reasons for which Rawls insists that the "basic structure of society should be organized in such a way that the inequalities in obtaining the primary goods of welfare, income, power and authority should be aimed at producing the greatest benefit for the least advantaged in obtaining primary goods".

This implies that equality carries with it diversity. As an illustration, L. Hierro, following Haussman and McPherson, discusses equality of welfare, equality of resources or primary goods, equality of opportunities for welfare, equality of capacity and complex equality. ${ }^{35}$ From the progressive liberal perspective, Rawls bases his argument on a concept of justice applied to the basic structure of the political and social system, and associates it with two principles: a) that "each person participating in a practice, or affected by it, has an equal right to the most extensive liberty compatible with a like liberty for all". and b) "inequalities (as permitted and defined by the pattern of distribution of rights and duties) are arbitrary unless it is reasonable to expect that they will work out for everyone's advantage and provided the positions and offices to which they attach, or from which they may be gained, are open to all". ${ }^{36}$ Rawls' plan is "to maximize the autonomy of each individual separately insofar it does not imply putting other individuals in a position of less comparative autonomy". For Nino, this reinforces the principle of personal dignity: the attribution of equal value to agreement between normal and adult individuals presupposes an equivalence between the possibilities of choice. Thus satisfaction of pri-

33) Giménez Glück 1999, pp. 52, 53.

34) Ferrajoli 2006, pp. 82, 83. One should not confuse 'difference' with 'inequality'. In this duality equality is based on diversity, which is opposed to 'homogeneity' and 'identity' (De Lucas 2000, p. 493). See also Añón Roig 2001.

35) Hierro 2002, p. 96.

36) Rawls 2001, pp. 104, 105. 
mary goods determines individual well-being. ${ }^{37}$ The work Political Liberalism not only introduces elements of justice, but also the objective basis for comparing individual situations of well-being between citizens. ${ }^{38}$

Dworkin presents an alternative of equality of resources, in a much less flexible position. Dworkin maintains that "given that liberal equality depends on economic and political mechanisms which reveal the real costs of opportunity of impersonal resources, an egalitarian society must be a free society. Invasions of liberty, such as criminal legislation which prohibits activities or styles of life that some people may wish to live or carry out, constitute invasions of equality, unless the need for them is justifiable, to protect an egalitarian distribution of resources and opportunities, providing security for persons or property, or for some other reason". ${ }^{39}$

According to Rawls and Dworkin, what is important is that there should be equality in satisfying basic needs allowing all persons to act as moral agents within a context, with an index which would postulate as a minimum that "justice would demand to satisfy all equally". Believing that no action which increased the distance from this minimum postulate would be justified, although equality could increase overall, the principle of difference would justify all kinds of actions which would take place and bring closer to the absolute minimum people who were at a lower level, despite the fact that the package of measures adopted represented a greater inequality. L. Hierro argues that if justice and effectiveness are related, it would have to be seen if it is possible to set a limit according to the satisfaction of the basic needs of the most advantaged members of society. ${ }^{40}$

The formula "for any good X, the just method of distribution consists in dividing X into equal parts" is a summary of egalitarianism, and enhances the rules of "to each the same" and "to all equally". The criticism made is that, bearing in mind that equal distribution is not always just, a distribution which allows the exercise of equal rights is just given the problem of shortage of goods. It corrects the preceding axioms through the joint maxims that "everyone has a right to a minim level of life, and the goods should be distributed in such a way that equal rights are satisfied", according to the concepts of 'minimum level of life', 'quality of life', 'basic needs' and

\footnotetext{
37) Nino 1989, pp. 345, 346.

38) On the commentary of the work of Rawls 2005, see J. Martínez de Pisón 1998, pp. 152, 153.

39) Dworkin 1993, pp. 89, 90; Dworkin 2000, pp. 75-131.

40) Hierro 2002, pp. 96-99, 102.
} 
'levels of life. ${ }^{41}$ To define substantive equality between individualism and collectivism as a basis for social rights, we have to maintain that it is based on 'equality to achieve a goal'. Substantive equality, and equality of substantive treatment, aspires to moral liberty, without forgetting the proper use of social, political and legal liberty and the rights which are based on it. ${ }^{42}$

In the words of Prieto Sanchís, the achievement of real equality by legal differentiations or inequalities is not obtained only through benefits. In addition, as we explained above, to know if something is equal it must be valued in relation to something else, using criteria which explain whether there are reasons for a different treatment. The key lies in deciding which real inequalities are arguable, and whether they are important enough to represent a sufficient reason when it comes to different treatment. ${ }^{43}$

\section{Final Note}

To sum up, understanding social rights is a dynamic and complex question. This complexity can be seen in the role played within the traditional decision-making powers governed by rules of exclusive and excluding competences. To this scheme can be added civil society and international bodies which create and strengthen new relations. ${ }^{44}$ Following J.S. Mill and Bentham, distributive justice is summarized according to the statement: "Between various possible distributions, a just distribution is that which proportions the greatest happiness possible to the greatest number of people". The problems arise because there are situations which oppose equality and which are not solved by utilitarianism; there are also inevitable inconveniences in an economic system in which supply and demand play a decisive role. ${ }^{45}$

We accept the defining argument of L. Hierro on equality, saying that "there has to be adequate resources among all human beings to satisfy basic needs, leaving each to develop his life plan in a similarly autonomous and free way". ${ }^{46}$ The tension between equality in practice and in law gives rise

41) Bobbio 1976, pp. 321-330.

42) Peces-Barba 1999a, pp. 289, 290; D. Giménez Glück 1999, pp. 45, 46.

43) Prieto 1998, pp. 81, 84, 90.

44) Barcellona 1996, p. 23.

45) Quintana 1994, p. 30-35.

46) Hierro 1995, p. 137. 
to a clash between principles. The problems that arise from these contradictions between theory and practice should be resolved using the techniques of deliberation. In answer to the question whether there is a general rule of preference, the answer lies in equality and not in differentiation. "There is always a reason for equality. Thus equality should be proposed so long as some real inequality does not offer a reason allowing or, depending on the conflicting arguments, imposing a differentiating regulation" ${ }^{47}$

There is a complementarity between equal opportunities and the achievement of substantial equality which justifies differentiated treatment as long as there is social inequality, so that minority groups do not remain marginalized. ${ }^{48}$ The transcendent importance of health, food, education, housing and culture is clear and manifest. At other times there are needs whose relevance does not seem so clear. ${ }^{49}$ In this case, Jori is right when he suggests that equality in legal capacity consists of "equal capacity to arrive at being unequal," as a way of putting into action "liberty as autonomy". As a footnote, the right to become and continue to be owner or debtor creates its guarantees related to the protection and ethical nature of the right to property or credit. The frontiers between fundamental and ownership rights have yet to be defined. ${ }^{50}$

\section{References}

Añón, M. José 1994, Necesidades y derechos. Un ensayo de fundamentación, Madrid: Centre for Constitutional Studies.

Añón, M. José 2001, Igualdad, diferencias y desigualdades, Mexico: Fontamara.

Añón, M. José and García Añón, José (coords.) 2002, Lecciones de derechos sociales, Valencia: Tirant lo Blanch.

Asís, Rafael de 1999, Una aproximación a los modelos de Estado de Derecho, Madrid: University of Jaén-Dykinson.

Barcellona, Pietro 1996, El individualismo propietario, translation of J.E. García Rodríguez, Madrid: Trotta.

47) Prieto 1998, p. 90.

48) Fariñas 1997, pp. 22. 23. This technique involves defective procedures which have to be changed. Peces-Barba has pointed out the great confusion caused in States offering general social rights, in which equality as a differentiation is an instrument for extending them to everyone, rather than for obtaining equivalence (Peces-Barba 1999c, p. 66).

49) Calsamiglia 1988, pp. 106-109; Fernández Ruiz-Gálvez 2003, p. 89; Pérez Luño 1981, pp. $255-257$.

50) Jori 2006, p. 128. 
Bayón, Juan Carlos 1991, La normatividad del Derecho: Deber juridico y razones para la acción, Madrid: Centre for Constitutional Studies.

Bobbio, Norberto 1976, 'Eguaglianza ed egualitarismo', Rivista Internazionale di Filosofia del Diritto, 53, 3: 321-330.

Bobbio, Norberto 2001, El problema del positivismo juridico, translation of E. Garzón Valdés, Mexico: Fontamara.

Bovero, Michelangelo 2007, 'Derechos fundamentales y democracia en la teoría de Ferrajoli. Un acuerdo global y una discrepancia concreta', in Antonio de Cabo and Gerardo Pisarello (eds.), Los fundamentos de los derechos fundamentales, pp. 215-242, Madrid: Trotta.

Böckenförde, Ernst Wolfgang 1993, Escritos sobre derechos fundamentales, translation of J.L. Requejo Pagés and I. Villaverde Menéndez, Baden-Baden: Nomos Verlag.

Calsamiglia, Albert 1988, 'Sobre el principio de igualdad', in Gregorio Peces-Barba (ed.), El fundamento de los derechos humanos, pp. 97-110, Madrid: Debate.

Contreras, Francisco J. 1994, Derechos sociales. Teoría e ideología, Madrid: Tecnos-Enrique Luño Peña Foundation.

Díaz, Elías 1998, Estado de Derecho y sociedad democrática, Madrid: Taurus.

Donati, Pierpaolo 1990, 'I diritti-doveri dei mondi vitali: l'Europa delle famiglie', Rivista Internazionale di Filosofia del Diritto, 67, 1: 51-81.

Dworkin, Ronald 1993, Ética privada e igualitarismo politico, translation of A. Doménech, Barcelona: Paidós-Autonomous University of Barcelona.

Dworkin, Ronald 2000, Sovereign Virtue: The Theory and Practice of Equality, Cambridge, MA: Harvard University Press.

Eekelaar, John 2000, 'Uncovering Social Obligations: Family Law and the Responsible Citizen', in Mavis Maclean (ed.), Making Law for Families, pp. 9-28, Oxford: The Oñati International Institute for the Sociology of Law-Hart Publishing.

Fariñas, M. José 1997, Los derechos humanos: desde la perspectiva sociológico-jurídica a la "actitud postmoderna", Madrid: Institute of Human Rights, Carlos III UniversityDykinson.

Fernández Ruiz-Gálvez, Encarnación 1992, 'Los derechos de las mujeres', in Jesús Ballesteros (ed.), Derechos humanos. Concepto, fundamentos, sujetos, pp. 144-162, Madrid: Tecnos. Fernández Ruiz-Gálvez, Encarnación 2003, Igualdad y derechos humanos, Madrid: Tecnos.

Ferrajoli, Luigi 2006, Derechos y garantías. La ley del más débil, translation of P. Andrés and A. Greppi, Madrid: Trotta.

Ferrajoli, Luigi 2007, 'Los derechos fundamentales en la Teoría del Derecho', in Antonio de Cabo and Gerardo Pisarello (eds.), Los fundamentos de los derechos fundamentales, pp. 139-196, translation of P. Andrés, A. de Cabo, M. Carbonell, L. Córdova, M. Criado and G. Pisarello, Madrid: Trotta.

García-Pelayo, Manuel 2005, Las transformaciones del Estado contemporáneo, Madrid: Alianza.

Garrido, M. Isabel 2007, Derechos fundamentales y Estado social y democrático de Derecho, Madrid: Dilex.

Giménez Glück, David 1999, Una manifestación polémica del principio de igualdad. Acciones positivas moderadas y medidas de discriminación inversa, Valencia: Tirant lo Blanch.

Guastini, Riccardo 1999, Distinguiendo. Estudios de teoría y metateoría del Derecho, translation of J. Ferrer, Barcelona: Gedisa. 
Häberle, Peter 2003: El Estado constitucional, translation of H. Fix-Fierro, Mexico: National Autonomous University of Mexico.

Harvey, David 2005, A Brief History of Neoliberalism, New York: Oxford University Press.

Hierro, Liborio 2002, Justicia, igualdad y eficiencia, Madrid: Centre for Constitutional Studies.

Jori, Mario 2007, 'Ferrajoli sobre los derechos', in Antonio de Cabo y Gerardo Pisarello (eds.), Los fundamentos de los derechos fundamentales, pp. 105-137, Madrid: Trotta.

Laporta, Francisco J. 1985, 'El principio de igualdad: Introducción a su análisis: introducción a su análisis', Sistema, 67: 3-31.

Locke, John 1982, Second Treatise of Government, ed. by Richard H. Cox, Arlington Heights: Harlan Davidson.

Lucas, Javier de 2000, 'La igualdad ante la ley', in Ernesto Garzón Valdés and Francisco J. Laporta, Derecho y justicia, pp. 493-500, Madrid: Trotta-Spanish Nacional Research Council.

Martínez de Pisón, José 1996, 'Libertad y Estado en la teoría liberal', Anuario de Filosofía del Derecho, XIII: 241-264.

Martínez de Pisón, José 1997, Derechos humanos. Historia, fundamento y realidad, Zaragoza: Egido.

Martínez de Pisón, José 1998, Políticas de bienestar. Un estudio sobre derechos sociales, Madrid: Tecnos.

Mill, John Stuart 2003, On Liberty, ed. D. Bromwich y G. Katelo, New Haven-Londres: Yale University Press.

Nino, Carlos Santiago 1989, Ética y derechos humanos. Un ensayo de fundamentación, Barcelona: Ariel.

Ollero, Andrés 1989, Igualdad en la aplicación de la ley y precedente judicial, Madrid: Centre for Political and Constitutional Studies.

Peces-Barba, Gregorio 1999a, Curso de derechos fundamentales. Teoría general, Madrid: Carlos III University-Official State Gazette.

Peces-Barba, Gregorio 1999b, 'De la función de los derechos fundamentales', in Gregorio Peces-Barba, Derechos sociales y positivismo jurídico. (Escritos de Filosofia Jurídica y Social), pp. 131-145, Madrid: Institute of Human Rights, Carlos III University-Dykinson.

Peces-Barba, Gregorio 1999c, 'Los derechos económicos, sociales y culturales. Apunte para su formación histórica y su concepto', in Gregorio Peces-Barba, Derechos sociales y positivismo jurídico. (Escritos de Filosofia Jurídica y Politica), pp. 7-66, Madrid: Institute of Human Rights, Carlos III University-Dykinson.

Pérez Luño, Antonio-Enrique 1981, 'El concepto de igualdad como fundamento de los derechos económicos, sociales y culturales', Anuario de Derechos Humanos, Institute of Human Rights, Complutense University of Madrid, 1: 257-275.

Preuss, Ulrich K. 1991, "El concepto de los derechos y el Estado del bienestar", translation of F. Serra, J. Aparicio and F. García Selgas, in Enrique Olivas (ed.), Problemas de legitimación en el Estado social, pp. 65-90, Madrid: Trotta.

Prieto, Luis 1995, 'Igualdad y minorías', Derechos y Libertades, 5: 111-154.

Prieto, Luis 1998, Ley, principios, derechos, Madrid: Institute of Human Rights, Carlos III University-Dykinson.

Rawls, John 2001, Justice as Fairness. A Restatement, ed. by E. Kelly, Cambridge-London: The Belknap Press of Harvard University Press. 
Rawls, John 2005, Political Liberalism, Nueva York: Columbia University Press.

Rivera, Eduardo 1997, Los presupuestos morales del liberalismo, Madrid: Centre for Political and Constitutional Studies.

Rosenfeld, Michel 1996, 'Towards a Reconstruction of Constitional Equality', in Andreas Sajo (ed.), Western Rights? Post-Communist Application, pp. 161-192, Dordrecht/ Bostón: Kluwer,

Santamaría, Javier 1997, Los valores superiores en la jurisprudencia del Tribunal Constitucional. Libertad, justicia, igualdad y pluralismo politico, Madrid: University of BurgosDykinson.

Tuori, Kaarlo 2002, Critical Legal Positivism, Aldershot: Ashgate.

Zimmerling, Ruth 1990, 'Necesidades básicas y relativismo moral', Doxa, 7: 35-54. 
Copyright of Societies Without Borders is the property of Brill Academic Publishers and its content may not be copied or emailed to multiple sites or posted to a listserv without the copyright holder's express written permission. However, users may print, download, or email articles for individual use. 